\title{
Silver Nanoparticles Surface-Modified with Carbosilane Dendrons as Carriers of Anticancer siRNA
}

\author{
Elżbieta Pędziwiatr-Werbicka ${ }^{1, *}$, Michał Gorzkiewicz ${ }^{1, *(D)}$, Katarzyna Horodecka ${ }^{1}$, \\ Viktar Abashkin 2 , Barbara Klajnert-Maculewicz 1,3, Cornelia E. Peña-González 4,5,6 (D), \\ Javier Sánchez-Nieves $4,5,6$ (D), Rafael Gómez ${ }^{4,5,6}$, F. Javier de la Mata ${ }^{4,5,6}$ (D) \\ and Maria Bryszewska ${ }^{1}$ (D)
}

1 Department of General Biophysics, Faculty of Biology and Environmental Protection, University of Lodz, 141/143 Pomorska St., 90-236 Lodz, Poland; katarzynahw@yahoo.es (K.H.); barbara.klajnert@biol.uni.lodz.pl (B.K.-M.); maria.bryszewska@biol.uni.lodz.pl (M.B.)

2 Institute of Biophysics and Cell Engineering of NASB, 27 Akademicheskaya St., 220072 Minsk, Belarus; viktar.abashkin@gmail.com

3 Leibniz Institute of Polymer Research Dresden, 6 Hohe St., 01069 Dresden, Germany

4 Department of Organic and Inorganic Chemistry and Research Chemistry Institute “Andrés M. del Río" (IQAR)., University of Alcalá, 28871 Alcalá de Henares, Spain; cornelia.pena@uah.es (C.E.P.-G.); javier.sancheznieves@uah.es (J.S.-N.); rafael.gomez@uah.es (R.G.); javier.delamata@uah.es (F.J.d.l.M.)

5 Networking Research Center for Bioengineering, Biomaterials and Nanomedicine (CIBER-BBN), 28029 Madrid, Spain

6 Institute "Ramón y Cajal" for Health Research (IRYCIS), 28034 Madrid, Spain

* Correspondence: elzbieta.pedziwiatr@biol.uni.lodz.pl (E.P.-W.); michal.gorzkiewicz@biol.uni.lodz.pl (M.G.)

Received: 29 April 2020; Accepted: 27 June 2020; Published: 30 June 2020

\begin{abstract}
Gene therapy is a promising approach in cancer treatment; however, current methods have a number of limitations mainly due to the difficulty in delivering therapeutic nucleic acids to their sites of action. The application of non-viral carriers based on nanomaterials aims at protecting genetic material from degradation and enabling its effective intracellular transport. We proposed the use of silver nanoparticles (AgNPs) surface-modified with carbosilane dendrons as carriers of anticancer siRNA (siBcl-xl). Using gel electrophoresis, zeta potential and hydrodynamic diameter measurements, as well as transmission electron microscopy, we characterized AgNP:siRNA complexes and demonstrated the stability of nucleic acid in complexes in the presence of RNase. Hemolytic properties of free silver nanoparticles and complexes, their effect on lymphocyte proliferation and cytotoxic activity on HeLa cells were also examined. Confocal microscopy proved the effective cellular uptake of complexes, indicating the possible use of this type of silver nanoparticles as carriers of genetic material in gene therapy.
\end{abstract}

Keywords: silver nanoparticles; carbosilane dendrons; siRNA; complexation; anticancer gene therapy

\section{Introduction}

Despite many years of intensive research, no satisfactory anticancer therapy has been developed so far. Gene therapy is one of the most promising approaches, based on the delivery of therapeutic nucleic acid molecules with different mechanisms of action in cancer cells. One of the proposed methods involves inhibiting or modulating gene expression by introducing small interfering RNAs (siRNAs) that specifically target and neutralize mRNA associated, e.g., with cell proliferation or their response to chemotherapeutic agents $[1,2]$. 
One of the biggest challenges of gene therapy involves the efficient delivery of siRNA inside the target cells. This is due to the specificity of nucleic acids, their low stability, susceptibility to enzymatic degradation, and negative charge hindering transport across cell membranes [3]. Therefore, research is directed at developing effective carriers of therapeutic nucleic acids that could overcome these obstacles [4]. Much attention in this regard is devoted to cationic nanoparticles, capable of forming stable non-covalent complexes with negatively charged nucleic acids. The application of such formulations provides protection of genetic material against degradation, as well as its efficient transport in the bloodstream and into the cells, which can significantly enhance the therapeutic effect [5].

Here, we focused on the possibility of using spherical silver nanoparticles (AgNPs) surface-modified with carbosilane dendrons as carriers of anticancer siRNA. The work was primarily aimed at in vitro characterization of the complexes, their stability in the presence of nucleotide enzymes, and their effect on human cells, including cytotoxicity and transfection efficacy.

\section{Results}

\subsection{Characterization of $A g N P: s i R N A$ Complexes}

The first step of the investigation involved the characterization of complexes of dendronized silver nanoparticles (Figure 1, Table 1) and siRNA (siBcl-xl). The ability of AgNPs to form complexes with siRNA as a function of the dendron:siRNA molar ratio was evaluated by electrophoresis in $3 \%$ agarose gel (Figure 2). Free siRNA in the gel is visible due to the GelRed intercalation. Nucleic acid in complex with silver nanoparticles cannot be stained with the dye or migrate in a gel in a degree comparable to free siRNA. Therefore, as the concentration of nanoparticles in the mixture increases, the amount of free nucleic acid decreases and thus the fluorescent signal associated with dye intercalation. This phenomenon enabled the determination of dendron:siRNA molar ratios at which the nucleic acid is completely complexed with silver nanoparticles (55:1 for 1Ag, 12.5:1 for 2Ag, and 7.5:1 for $3 \mathrm{Ag}$ ). The molar ratio decreased with the increase of the generation of dendrons on the surface of silver nanoparticles.

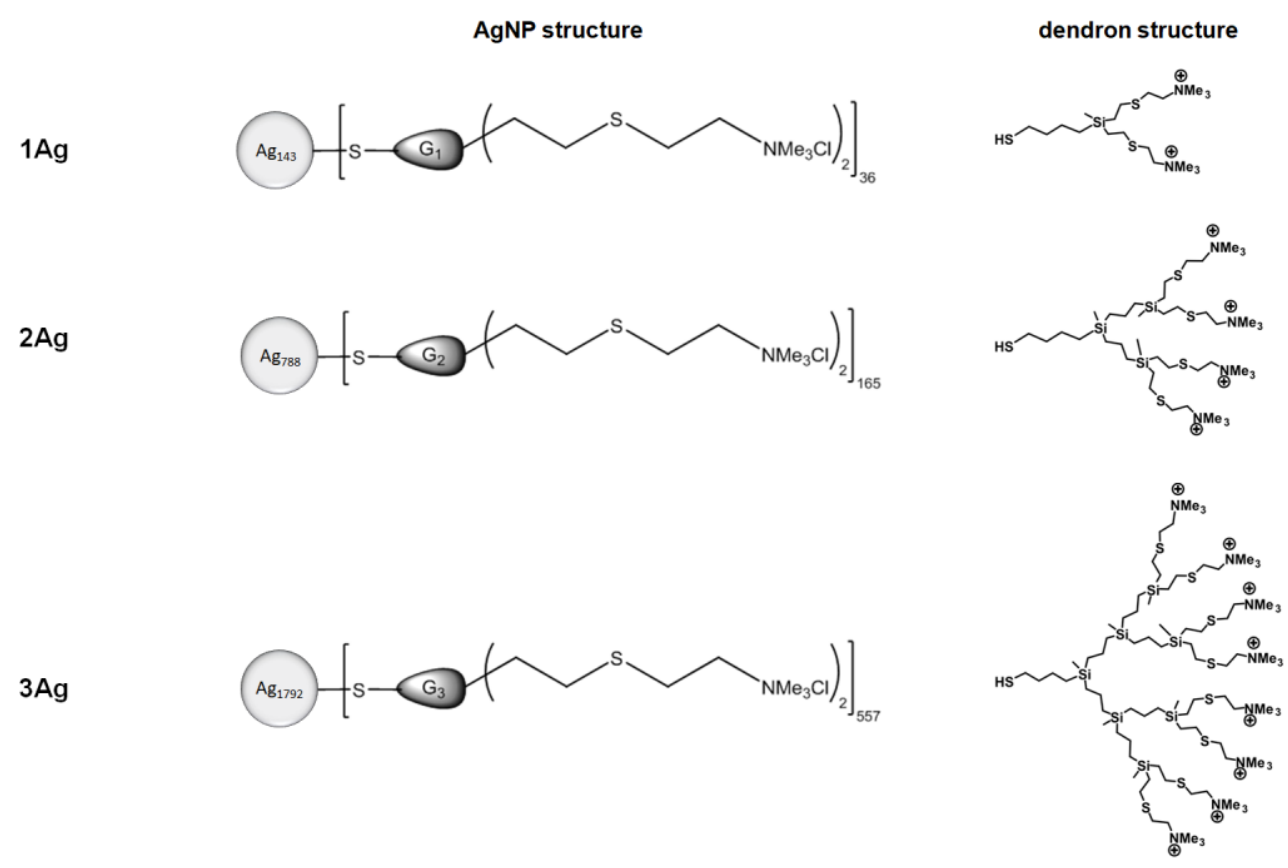

Figure 1. Chemical structures of the studied AgNPs. 
Table 1. Characteristics of the studied AgNPs.

\begin{tabular}{|c|c|c|c|}
\hline AgNP & \multicolumn{2}{|c|}{ Molecular Formula } & Molecular Weight (g/mol) \\
\hline 1Ag & \multicolumn{2}{|c|}{$\mathrm{Ag}_{143}\left(\mathrm{C}_{19} \mathrm{H}_{45} \mathrm{Cl}_{2} \mathrm{~N}_{2} \mathrm{~S}_{3} \mathrm{Si}\right)_{36}$} & $33,309.85$ \\
\hline $2 \mathrm{Ag}$ & \multicolumn{2}{|c|}{$\mathrm{Ag}_{788}\left(\mathrm{C}_{41} \mathrm{H}_{97} \mathrm{Cl}_{4} \mathrm{~N}_{4} \mathrm{~S}_{5} \mathrm{Si}_{3}\right)_{165}$} & $255,383.86$ \\
\hline 3Ag & \multicolumn{2}{|c|}{$\mathrm{Ag}_{1792}\left(\mathrm{C}_{85} \mathrm{H}_{201} \mathrm{Cl}_{8} \mathrm{~N}_{8} \mathrm{~S}_{9} \mathrm{Si}_{7}\right)_{557}$} & $1,365,420.42$ \\
\hline & \multicolumn{3}{|c|}{ dendron:siRNA molar ratio } \\
\hline & SIRNA & 45 & 60 \\
\hline
\end{tabular}
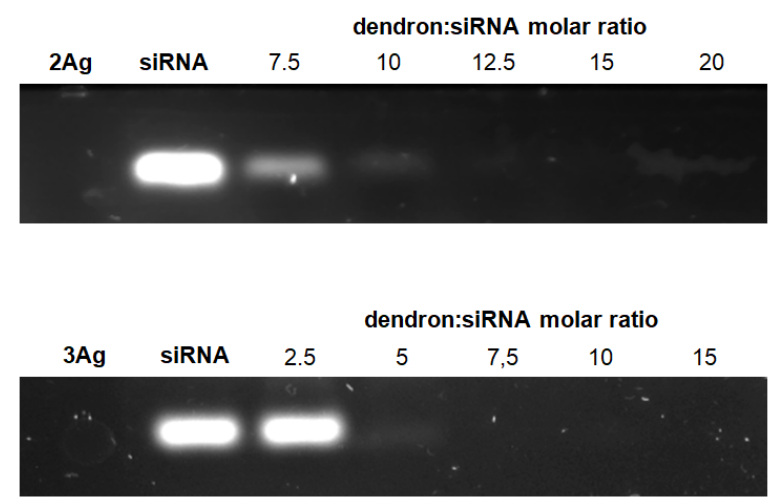

Figure 2. Electrophoresis of AgNP:siRNA complexes at varying dendron:siRNA molar ratios.

Further, we showed that the complexation with AgNPs provides protection of siRNA from the action of RNase (Figure 3). Free nucleic acid in the presence of enzyme is almost completely degraded, whereas incubation with silver nanoparticles protects siRNA from RNase (the addition of heparin before electrophoresis led to siRNA release from the complexes and its migration in the gel).

To confirm the dendron:siRNA molar ratios determined by gel electrophoresis and to assess the surface electrostatic potential of complexes, we performed titration with zeta potential measurement (Figure 4). Titration curves showed surface potential change due to nucleic acid complexation with the studied AgNPs. Upon the addition of silver nanoparticles to the siRNA solution, the initial zeta potential of free nucleic acid (approximately $-12 \mathrm{mV}$ ) increased with an increasing concentration of AgNPs, until reaching a plateau at approximately $+15 \mathrm{mV}$. The curves were used to determine the binding stoichiometry (using the two-tangent method). The number of dendrons on the surface of AgNPs per one siRNA molecule equaled $\sim 60$ for $1 \mathrm{Ag}, \sim 11$ for $2 \mathrm{Ag}$, and $\sim 6$ for $3 \mathrm{Ag}$, which correlated with the dendron:siRNA molar ratios determined by electrophoresis. Further, these experiments allowed the positive surface electrostatic potential of the studied complexes to be shown.

A

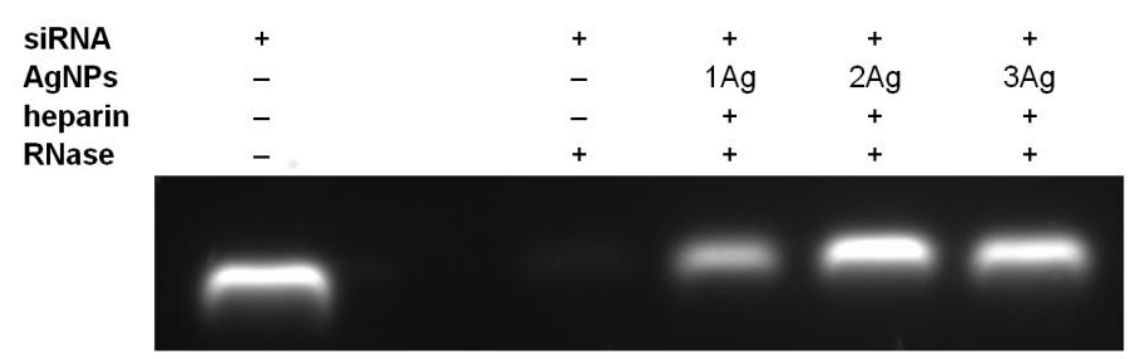

Figure 3. Cont. 
B

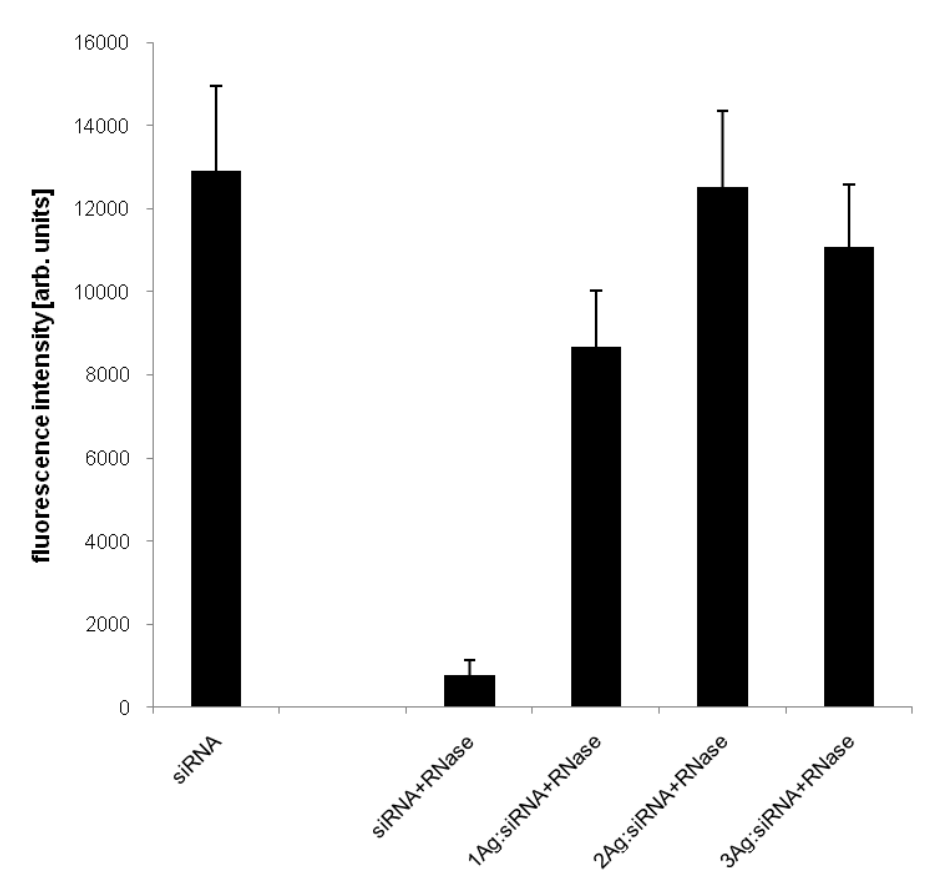

Figure 3. Protective effect of AgNPs towards siRNA (siBcl-xl) treated with RNase. (A) The first lane demonstrates migration of non-complexed siRNA. The third lane shows migration of siRNA incubated with RNase A/T1 $(10 \mu \mathrm{g} / \mathrm{mL})$ for $30 \mathrm{~min}$ at $37^{\circ} \mathrm{C}$. The following lanes show the migration of siRNA released from complexes with AgNPs, indicating the protection of siRNA from enzymatic cleavage. (B) Quantification (by computer image analysis using ImageJ software) of bands in the gel. Data presented as the percentage of band intensity, mean $\pm \mathrm{SD}, n=3$.

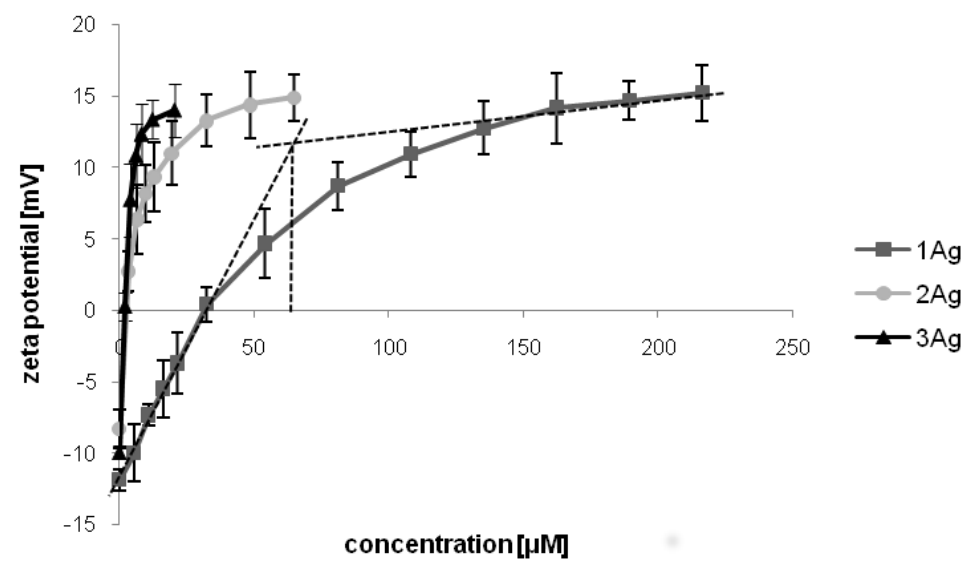

Figure 4. Changes in the zeta potential during the titration of siRNA (siBcl-xl) with AgNPs. The abscissa values refer to the dendron concentration. Data presented as mean $\pm \mathrm{SD}, n=3$ (8 measurements each). The dashed lines illustrate the determination of the maximum dendron:siRNA ratio in a complex with the use of the two-tangent method.

The hydrodynamic diameter of complexes was assessed by the dynamic light scattering (DLS) method (Figure 5). The size of the complexes in the dendron:siRNA molar ratios determined by electrophoresis equaled $\sim 430 \mathrm{~nm}$ (PDI $\sim 0.45$ ) for $1 \mathrm{Ag}, \sim 614 \mathrm{~nm}$ (PDI $\sim 0.37$ ) for $2 \mathrm{Ag}$, and $\sim 615 \mathrm{~nm}$ (PDI $\sim 0.25$ ) for $3 \mathrm{Ag}$. Additional experiments for complexes in higher dendron:siRNA molar ratios showed a marked increase in the hydrodynamic diameter of complexes accompanied by higher PDI values, suggesting the formation of aggregates. 


\section{A}

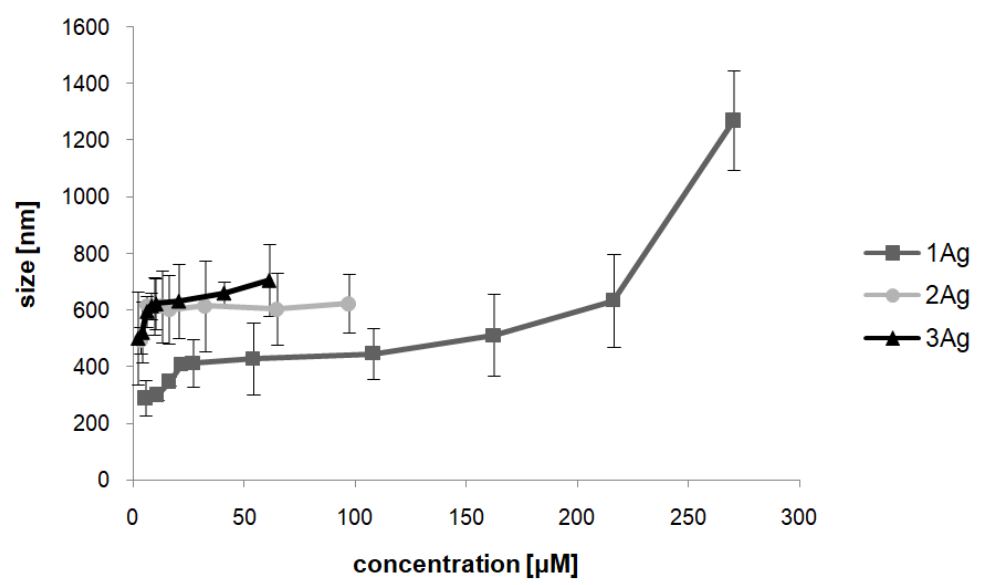

B

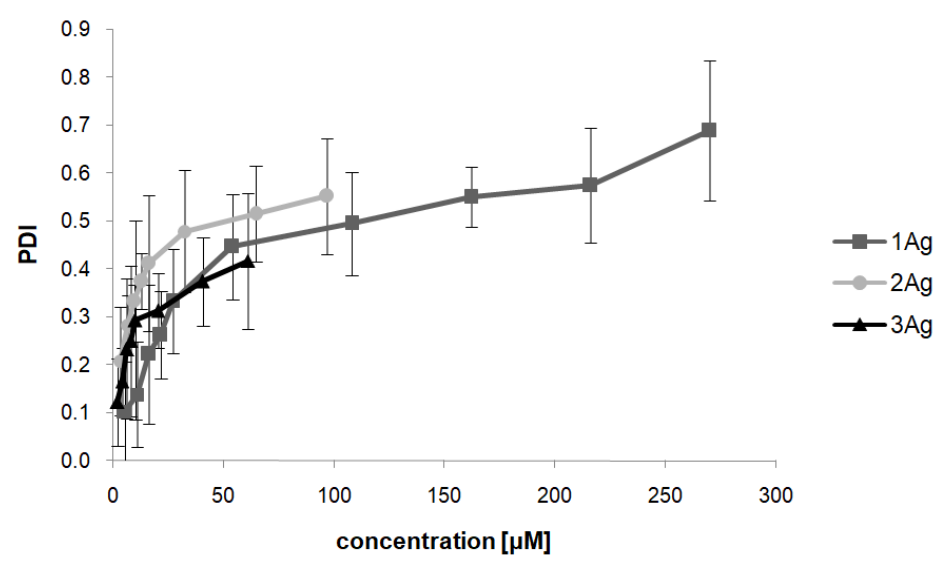

Figure 5. Changes in the hydrodynamic diameter (A) and polydispersity index (B) of AgNP:siRNA (siBcl-xl) complexes as a function of increasing concentrations of AgNPs. The abscissa values refer to the dendron concentration. Data presented as mean $\pm \mathrm{SD}, n=3$ ( 8 measurements each).

The morphological structure of 2Ag:siRNA complexes prepared in a 12.5:1 dendron:siRNA molar ratio was visualized by transmission electron microscopy (TEM) (Figure 6), which confirmed the size and heterogeneous organization of the complex assessed by hydrodynamic diameter measurements.
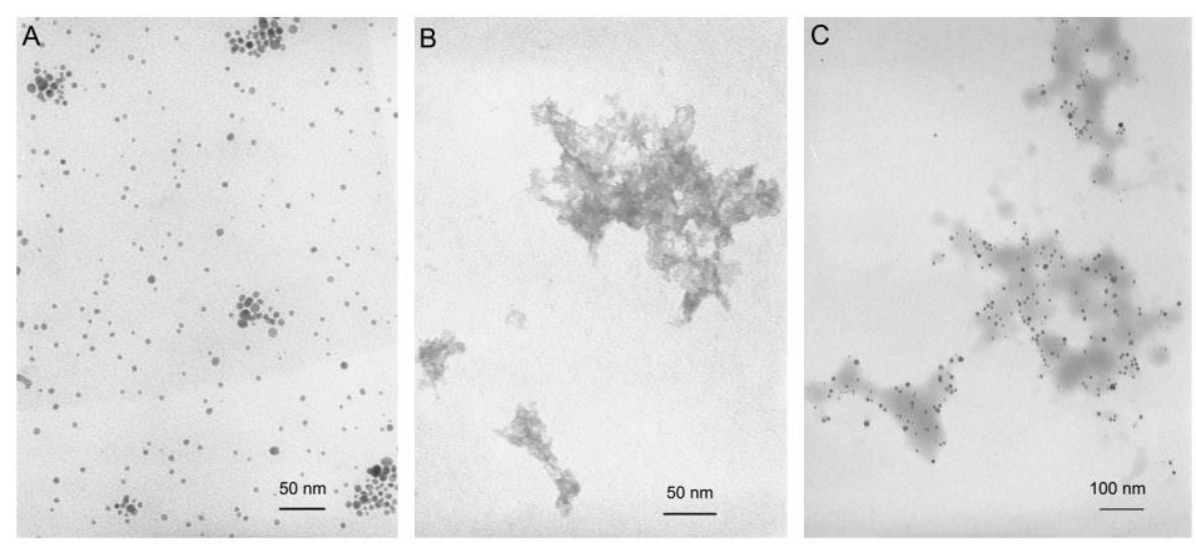

Figure 6. Ultrastructure of 2Ag nanoparticles (A), siRNA (siBcl-xl) (B), and 2Ag:siRNA (siBcl-xl) complexes prepared in a 12.5:1 dendron:siRNA molar ratio (C). 


\subsection{Impact of Dendronized Silver Nanoparticles and AgNP:siRNA Complexes on Human Cells}

The ability of AgNPs to deliver siRNA into HeLa cells was proved by confocal microscopy (Figure 7), with FITC-siRNA inside the cells being visible as green spots. This technique also showed that the treatment with complexes at given concentrations does not change the morphology of the cells. Thus, the next step involved the characterization of the hemolytic and cytotoxic activity of the studied nanoparticles and their complexes with siRNA over the range of concentrations.
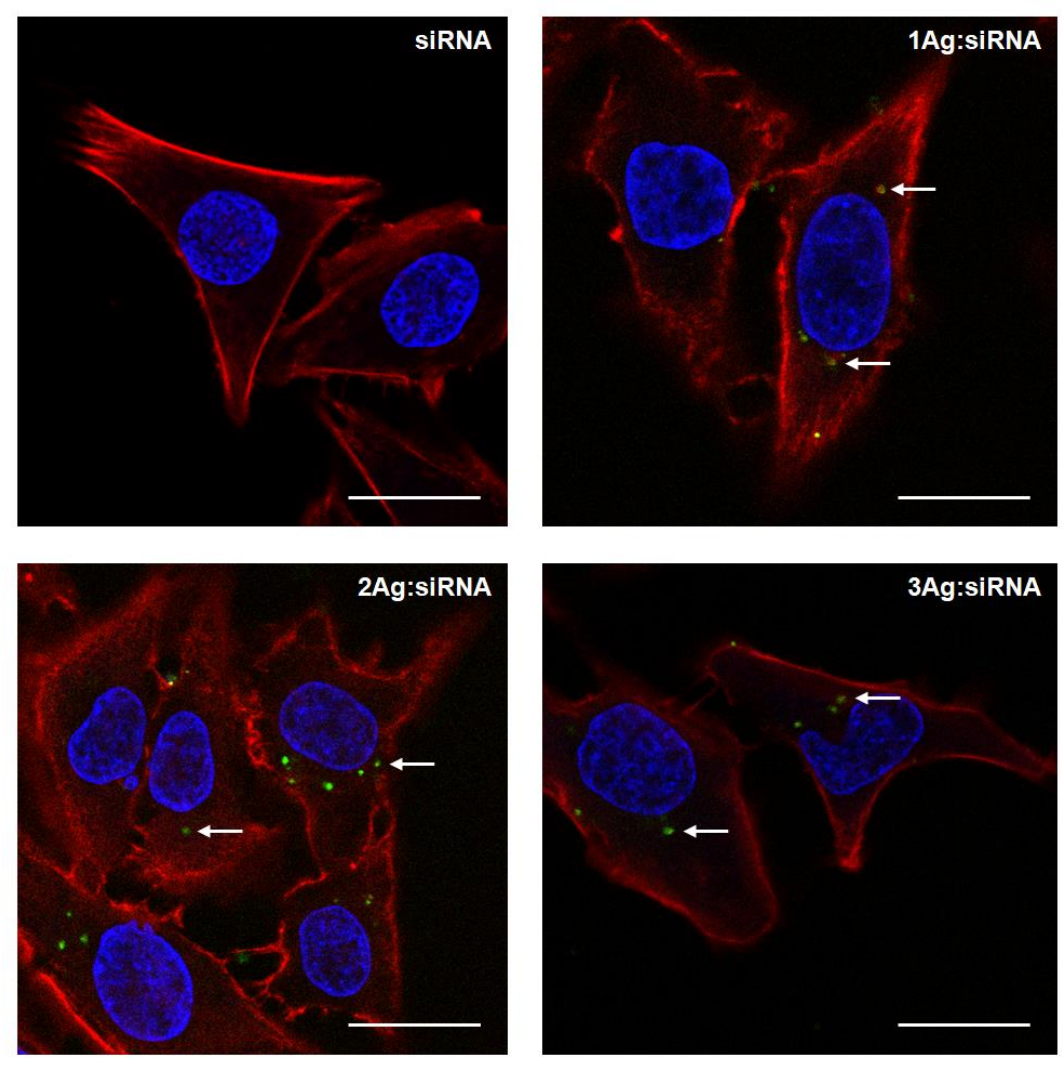

Figure 7. Confocal microscopy images of HeLa cells after $24 \mathrm{~h}$ of incubation with free FITC-labeled siRNA (siBcl-xl, $100 \mathrm{nM}$ ) or its complexes with 1Ag, 2Ag, and 3Ag prepared in dendron:siRNA molar ratios of 55:1, 12.5:1, and 7.5:1, respectively. Bar $=10 \mu \mathrm{m}$. White arrows indicate FITC-labeled siRNA inside the cells.

Hemolysis induced by silver nanoparticles and AgNP:siRNA complexes depended on the concentration of tested compounds and the incubation time (Figure 8). The degree of hemolysis increased with the increase of dendron generation; it was also higher after a longer incubation time. The complexes showed lower hemolytic activity compared to free AgNPs in the case of $1 \mathrm{Ag}(\operatorname{after} 24 \mathrm{~h})$ and $3 \mathrm{Ag}$ (after 2 and $24 \mathrm{~h}$ ).

Inhibition of lymphocyte proliferation also depended on dendron generation. The weakest inhibiting activity was observed for $1 \mathrm{Ag}$, while for $2 \mathrm{Ag}$ and $3 \mathrm{Ag}$ the effect was comparable. There was no statistically significant difference between the activity of the AgNP:siRNA complexes and free nanoparticles at the same dendron concentrations (Figure 9). 
A

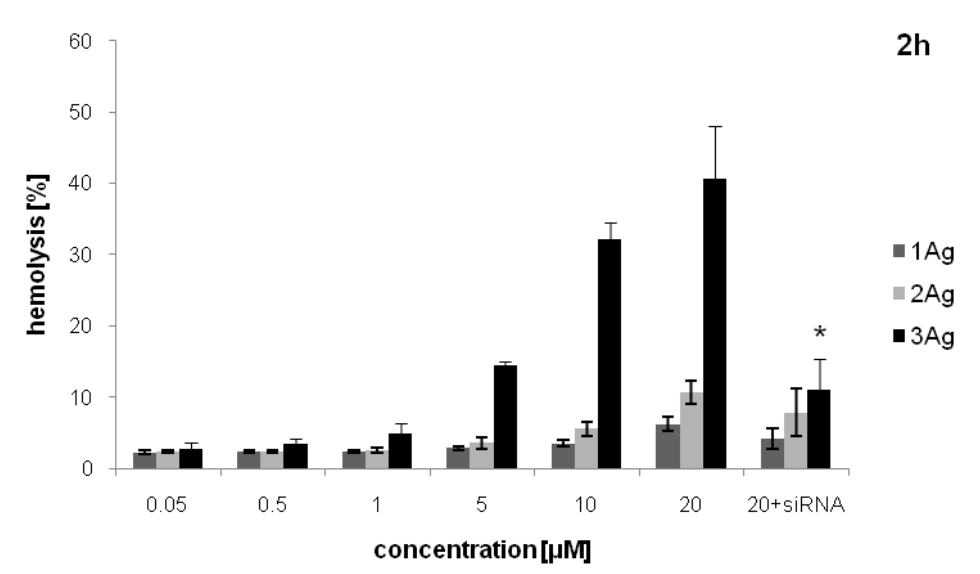

B

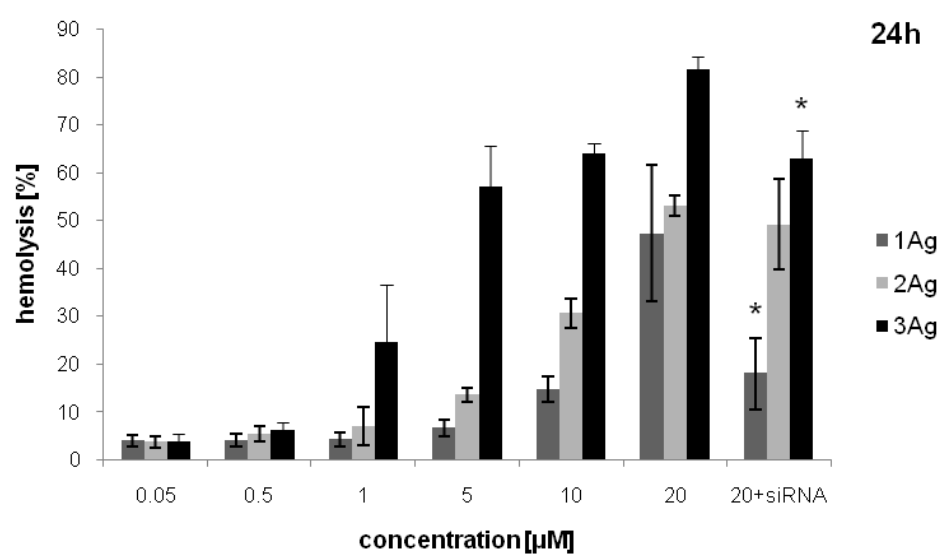

Figure 8. Hemolysis induced by AgNPs and their complexes with siRNA (siBcl-xl) after 2 (A) and $24 \mathrm{~h}$ of incubation (B). The abscissa values refer to the dendron concentration. Data presented as the percentage of hemolysis, mean $\pm \mathrm{SD}, n=4$. ${ }^{*}$ Statistically significant difference compared to free nanoparticle at $p<0.05$.

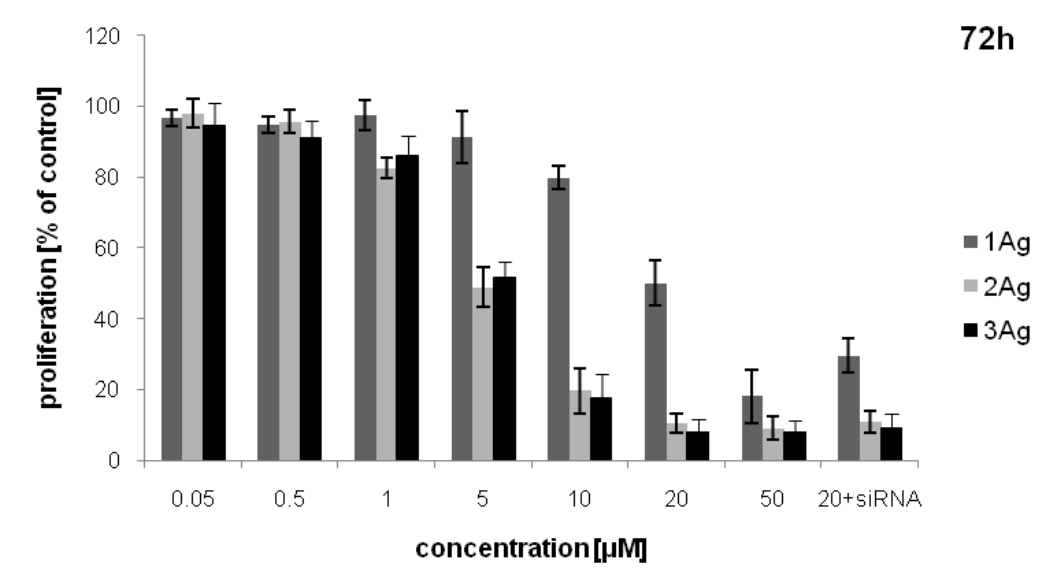

Figure 9. Inhibition of lymphocyte proliferation by AgNPs and their complexes with siRNA (siBcl-xl) after $72 \mathrm{~h}$ of treatment. The abscissa values refer to the dendron concentration. Data presented as percentage of viability of control (PHA-treated) cells, mean $\pm \mathrm{SD}, n=3$.

The cytotoxicity of the tested compounds was evaluated on HeLa cells (Figure 10). Similarly to the hemolysis studies, the cytotoxic activity depended on the concentration of the tested compounds and incubation time, increasing in the case of $1 \mathrm{Ag}$ and decreasing for $2 \mathrm{Ag}$ and $3 \mathrm{Ag}$ between 2 and 
$24 \mathrm{~h}$ of incubation. The cytotoxic effect increased with the dendron generation (in the case of $1 \mathrm{Ag}$, it was lower compared to $2 \mathrm{Ag}$ and $3 \mathrm{Ag}$ (Figure 10A,B)). No difference in cytotoxicity was observed comparing the complexes and free nanoparticles at the same dendron concentration; only for 2Ag after $3 \mathrm{~h}$ of incubation the complex showed significantly lower activity (Figure 10C).

A

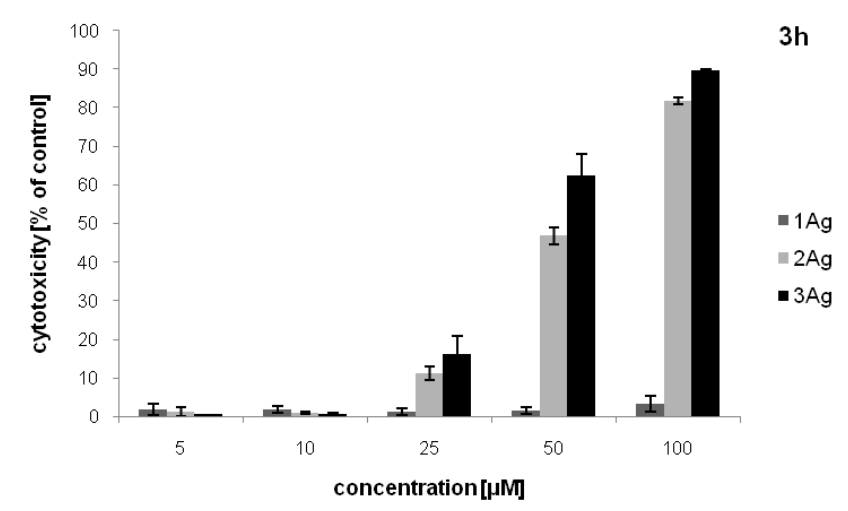

B

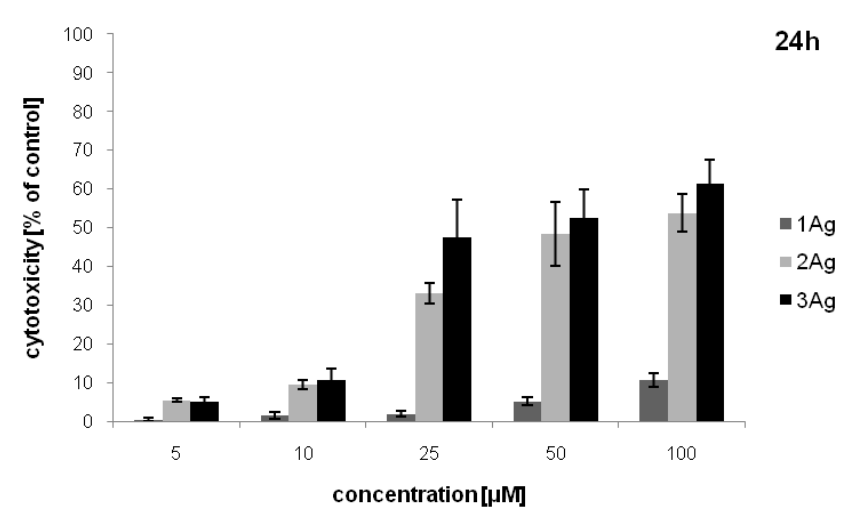

C

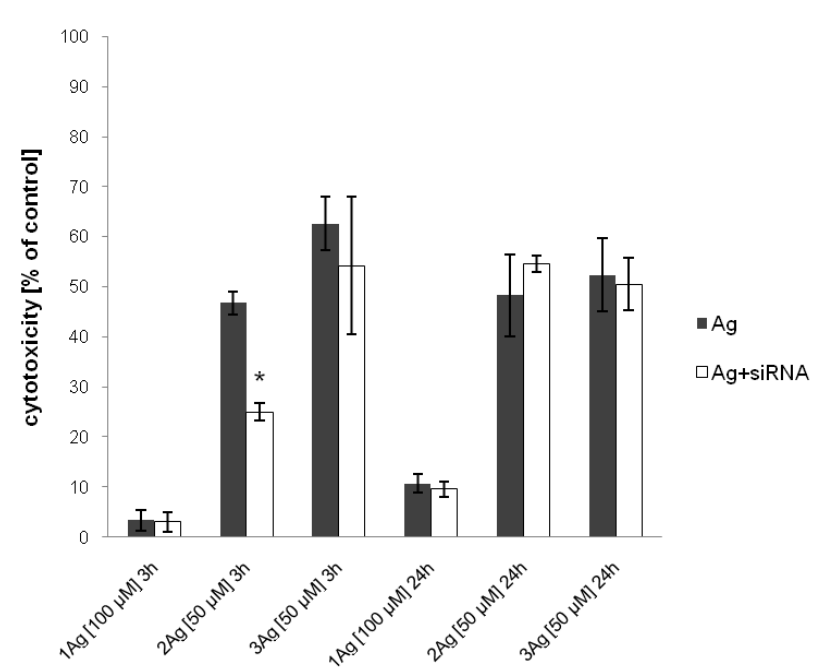

Figure 10. Cytotoxic effect of AgNPs (A,B) and their complexes with siRNA (siBcl-xl) (C) on HeLa cells. Viability was determined by the LDH assay after 3 and $24 \mathrm{~h}$ of treatment. The abscissa values refer to the dendron concentration. Data presented as the percentage of cytotoxicity compared to control (untreated) cells, mean $\pm \mathrm{SD}, n=3$. * Statistically significant difference compared to free nanoparticle at $p<0.05$. 


\section{Discussion}

One of the most promising approaches in modern gene therapy exploits RNA interference (RNAi), a biological process in which RNA molecules inhibit gene expression by targeting and neutralizing mRNA. This effect may be mediated by two types of small RNA molecules, microRNA (miRNA) and siRNA [6]. Since its discovery in 1990s, RNAi quickly attracted the attention of scientists due to the wide range of potential applications in the treatment of viral infections, neurological disorders, and cancer. The use of RNAi in the therapy of the latter is particularly interesting, providing a more specific approach to reduce tumor growth by targeting cancer-related genes, enhance the sensitivity of cancer cells to chemotherapeutics, or inhibit cell invasion and migration [1,2].

In order to exhibit an anticancer effect, therapeutic RNA molecules must be efficiently transported into the cell to reach its molecular targets. This step is a major obstacle for the development of effective gene therapy due to the negative charge, structural stiffness, and high sensitivity to enzymatic degradation of nucleic acids. These features significantly hamper the transport of nucleic acids in the bloodstream, across cellular membranes, and between intracellular compartments [3,7,8]. Thus, effective delivery systems are currently being sought to overcome these barriers. An appropriate carrier for a therapeutic nucleic acid should primarily provide its protection against the activity of nucleases, extended blood half-life, efficient and specific transport to the tumor area and into the target cells, as well as intracellular release [4].

Initially, viruses seemed to be the best candidates for carriers in gene therapy because of their innate ability to introduce nucleic acids into eukaryotic cells, providing efficient transfection and long-term silencing of gene expression. However, it soon became apparent that viral carriers have serious drawbacks due to the high cost of production, along with the induction of immune responses and generation of various side effects, lowering the therapeutic effect. Thus, researchers began to look for non-viral delivery systems [9-11].

At present, the most commonly studied non-viral carriers for nucleic acids are based on nanomaterials, including liposomes, carbon nanotubes, or dendrimers. However, their application, despite a high transfection efficacy and facile production, remains limited because of low stability, weak targeting potential, and difficult in vivo tracking [12,13]. Metal nanoparticles constitute an interesting alternative due to their unique size- and shape-dependent physicochemical properties [14,15]. These include high storage stability, as well as significant reactivity and large surface area, enabling a wide range of functionalization of nanoparticles. Appropriate selection of surface modifications may further increase the stability, bioavailability, and targeting potential of metal nanoparticles, but most importantly, provide a positive surface electrostatic potential, enabling interactions with negatively charged nucleic acid molecules. This may enable the formation of stable non-covalent complexes, capable of intracellular delivery of nucleic acids and their protection against enzymatic degradation [16]. Therapeutic nucleic acids can be attached directly to metal nanoparticles by covalent bonds. This solution, however, might significantly affect their structure and hinder release inside the cell [17]. For the purpose of generating a surface positive charge, metal nanoparticles were modified with quaternary ammonium, poly(ethyleneimine) (PEI), triethylenetetramine (TETA), chitosan, amino acids, etc. [16-18]. Non-covalent complexes based on electrostatic interactions showed enhanced delivery and increased anticancer activity, with the strength of these effects dependent mainly on the nanoparticle:nucleic acid ratio and surface electrostatic potential of the systems [17].

In the present work, we explored the possibility of using silver nanoparticles surface-modified with carbosilane dendrons as carriers of anticancer siRNA. Although gold nanoparticles (AuNPs) have been more thoroughly tested for the delivery of therapeutic nucleic acids due to high stability and resistance to oxidation, silver nanoparticles can be a valuable alternative due to their lower price and higher reactivity, increasing the range of possibilities of surface functionalization $[16,19,20]$. Since cationic carbosilane dendrimers of low cytotoxicity were previously shown to form stable complexes with siRNA [21,22], increasing its intracellular delivery and toxic effect [23], we chose carbosilane dendrons as a coating of spherical AgNPs. Such silver nanoparticles (also additionally 
modified with polyethylene glycol (PEG) chains) were studied only for their antibacterial and antifungal properties [24-26]; therefore, this is the first report on their application as carriers of siRNA.

Carbosilane dendrons of different generations and dendron-coated gold nanoparticles were previously characterized in terms of their interactions with plasma proteins $[27,28]$, induction of hemolysis, effect on platelet aggregation, and lymphocyte proliferation [29]. Interestingly, their ability to limit HIV replication in infected PBMCs by intracellular delivery of siRNA Nef was also examined; however, neither dendron:siRNA nor AuNP:siRNA complexes showed enhanced activity compared to free nucleic acid [29].

In this study, we assessed the formation, stoichiometry, and properties of complexes of studied AgNPs and anticancer siRNA (siBcl-xl) (as a function of the dendron concentration), their ability to protect nucleic acid from enzymatic degradation, and to deliver it inside cancer cells. The effect of free nanoparticles and complexes on human cells (erythrocytes, PBMCs, and HeLa) was also evaluated. We chose anti-Bcl-xl siRNA since this anti-apoptotic protein is frequently overexpressed in many tumors and plays a crucial role in cancer progression [30], making it a good target for gene therapy [31,32].

Using gel electrophoresis, the method commonly applied for the analysis of nucleic acids' complexation by nanoparticles [29,33-35], we determined the dendron:siRNA molar ratios corresponding to the maximum saturation of siRNA by AgNPs. As anticipated, the dendron:siRNA molar ratios decreased with increasing nanoparticle/dendron generation, which correlated with the increase in the number of dendron's positively charged $-\mathrm{NMe}_{3}{ }^{+}$groups (Figure 1, Table 1), indicating the formation of complexes based on electrostatic interactions. The complexes also showed the ability to protect siRNA against RNase activity, which was previously observed for different nanoparticles [36,37].

The stoichiometric ratios of complexes determined by gel electrophoresis were confirmed by measurement of changes in the zeta potential during titration of siRNA with AgNPs $[37,38]$. Further, this assay showed the positive surface electrostatic potential of complexes, which was also demonstrated for dendriplexes [39-41], including those formed by carbosilane dendrimers and siBcl-xl [22,42]. This feature is crucial for the intracellular delivery of the cargo, since positively charged nanosystems can penetrate cell membranes more effectively than neutral or negatively charged ones [43]. It could also suggest that siRNA is covered with nanoparticles; however, considering the molar concentration of the whole AgNP instead of dendron in the complex, it is clear that there is roughly one or less silver nanoparticles per one siRNA molecule. This may be partially explained by nucleic acids wrapping around positively charged spherical metal nanoparticles, thereby creating a chromatin-like structure [44].

The hydrodynamic diameters of the complexes, supported by TEM images, are relatively large $(\sim 500 \mathrm{~nm})$, and high values of the polydispersity index, especially at higher dendron:siRNA molar ratios, indicate the formation of aggregates $[45,46]$. It should be noted, however, that the size determined by DLS is usually larger than that observed by TEM due to the increased light scattering by bigger particles, which shifts the measured particle size towards higher values [29]. TEM images are therefore more accurate. Nevertheless, it was previously shown that dendriplexes based on poly(amidoamine) (PAMAM), phosphorus, and carbosilane dendrimers, characterized by similar sizes, can effectively transport nucleic acids into the cells $[22,23,40,47]$.

The therapeutic application of nanoparticles often involves intravenous administration. Therefore, it is crucial to characterize their effects on blood cells before starting any in vivo testing. AgNPs surface-modified with carbosilane dendrons showed concentration- and dendron generation-dependent hemolysis and inhibition of lymphocyte proliferation. In case of hemolysis, the effect was also time-dependent. The nanoparticles showed high hemolytic activity after $2 \mathrm{~h}$ of incubation above the $20 \mu \mathrm{M}$ (for $1 \mathrm{Ag}$ and $2 \mathrm{Ag}$ ) and $5 \mu \mathrm{M}$ (for $3 \mathrm{Ag}$ ) dendron concentration, which indicates the possibility of the application of AgNP:siRNA complexes in the lower, non-hemolytic range of the dendron concentration. In addition, siRNA complexation reduced the level of hemolysis (especially in the case of $3 \mathrm{Ag}$ ). Similar results were obtained for free carbosilane dendrons and dendron-modified AuNPs, with minor discrepancies most likely due to differences in the structure of nanoparticles 
and concentration/distribution of dendrons on their surface [29]. From these results, we postulate that the observed effects are related to dendrons, their charge, and generation, and to a lesser extent to the silver core of nanoparticles. Although the toxicity of non-modified metal nanoparticles was reported to be size- and shape-dependent, the data are inconsistent. On the other hand, the surface functionalization significantly influences their properties, including cytotoxicity, cellular uptake, and biodistribution $[17,48]$. Although a positive surface charge of nanoparticles improves the efficacy of gene transfer and drug delivery, a higher cytotoxicity of such systems was reported due to the disruption of cellular membranes' integrity, damage of mitochondria, generation of reactive oxygen species (ROS), etc. [49]. The AgNP:siRNA complexes also inhibited lymphocyte proliferation and caused hemolysis, although for the latter the effect was less visible compared to free nanoparticles. This is most probably also associated with the positive charge on the surface of the complexes. Interestingly, the incubation of carbosilane dendrons and dendronized AuNPs with human serum albumin (HSA) limited their hemolytic effect [29]. This supports the hypothesis regarding the role of positively charged dendrons in the induction of hemolysis, and indicates potentially lower impact of carbosilane dendron-coated nanoparticles on blood cells in vivo due to their interactions with plasma proteins.

The cytotoxic activity of dendronized AgNPs on HeLa cells was also dendron generationdependent, with $1 \mathrm{Ag}$ being the least toxic. The cytotoxicity of $2 \mathrm{Ag}$ and $3 \mathrm{Ag}$ was lower after $24 \mathrm{~h}$ of incubation compared to that observed after $3 \mathrm{~h}$, which may be related to the specificity of the LDH assay and cell growth. In this case, the LDH leakage from damaged cells was measured, whereas intact cells (including untreated control) continued to divide, resulting in underestimated values after prolonged incubation. This observation further confirms the mechanism of cytotoxicity based primarily on membrane damage by positively charged nanoparticles. The use of other cytotoxicity test, such as MTT, neutral red, or resazurin assay, could show the toxicity increasing over time.

Despite intracellular delivery of siRNA by AgNPs (demonstrated by confocal microscopy), no increase in cytotoxic activity of AgNP:siRNA complexes was found compared to free nanoparticles. This may be due to several factors, including hampered endosomal escape after endocytosis, limited release of siRNA from complexes, or an inadequate amount of intracellularly delivered siRNA to exert its cytotoxic effect [42]. On the other hand, the expression of Bcl-xl and other proteins of Bcl-2 family in HeLa cells is relatively low ([50,51], www.proteinatlas.org), which at the present stage makes it impossible to draw unequivocal conclusions about the effectiveness of the proposed siRNA delivery vehicles. This in turn encourages further work both on the delivery system and the selection of appropriate therapeutic nucleic acids for specific cellular models.

\section{Materials and Methods}

\subsection{Dendronized Silver Nanoparticles}

AgNPs surface-modified with cationic carbosilane dendrons of different generations (Figure 1, Table 1) were synthesized and characterized as described previously [24].

\subsection{Short Interfering $R N A$}

Non-fluorescent and fluorescein (FITC)-labeled anti-Bcl-xl siRNAs (siBcl-xl) (sense: 5'CAGGGACAGCAUAUCAGAGdTdT3', antisense: 5'CUCUGAUAUGCUGUCCCUGdTdT3') were synthesized (Dharmacon Inc., Lafayette, CO, USA) and dissolved in RNase-free water prior to experimental use. 


\subsection{Characterization of AgNP:siRNA Complexes}

\subsubsection{Gel Electrophoresis}

Complexes of siRNA $(1.5 \mu \mathrm{M})$ and AgNPs in different dendron:siRNA molar ratios were prepared in $10 \mathrm{mM}$ phosphate buffer, $\mathrm{pH} 7.4$, and incubated for $20 \mathrm{~min}$ at room temperature. Then the samples were placed on 3\% agarose gel containing GelRed stain (Biotium, Fremont, CA, USA) and separated by electrophoresis in Tris-acetate-EDTA (TAE) buffer for $45 \mathrm{~min}$ at $90 \mathrm{~V} / 35 \mathrm{~mA}$. The gel was subsequently visualized using UV light and a digital picture of the stained gel was taken with UVP ChemiDoc-It $2^{\mathrm{TM}}$ Imager (Thermo Fisher Scientific, Waltham, MA, USA).

To study the protection of siRNA against enzymatic degradation as a result of complexation with AgNPs, the complexes in dendron:siRNA molar ratios of 55:1, 12.5:1, and 7.5:1 were prepared for $1 \mathrm{Ag}, 2 \mathrm{Ag}$, and $3 \mathrm{Ag}$, respectively. The samples were incubated with RNase A/T1 (Thermo Fisher Scientific, Waltham, MA, USA, $10 \mu \mathrm{g} / \mathrm{mL}$ ) for $30 \mathrm{~min}$ at $37{ }^{\circ} \mathrm{C}$ and $10 \mathrm{~min}$ on ice. Heparin (Sigma Aldrich, St. Louis, MO, USA, $0.082 \mathrm{mg} / \mathrm{mL}$ ) was added to the samples for $10 \mathrm{~min}$ to release siRNA from the complexes. Samples prepared in this way were analyzed by electrophoresis in a manner analogous to that described above.

Band intensities were quantified digitally using ImageJ software and presented as mean $\pm S D$, $n=3$.

\subsubsection{Size and Zeta Potential Measurements}

Measurements of size and zeta potential were performed with the use of a Zetasizer Nano ZS (Malvern Instruments Ltd., Malvern, UK). Complexes were prepared in phosphate-buffered saline (PBS) by mixing siRNA $(1 \mu \mathrm{M})$ with an increasing concentration of nanoparticles (different dendron:siRNA molar ratios), placed in the low-volume sizing cuvettes (ZEN0112, Malvern Instruments Ltd., Malvern, UK) for size determination or in the folded capillary cells (DTS 1070, Malvern Instruments Ltd., Malvern, $\mathrm{UK})$ for zeta potential measurements at $37^{\circ} \mathrm{C}$. The data were analyzed using Malvern software. Particle size distribution was determined by a multimodal peak analysis. When the polydispersity index (PDI) was lower than 0.5, Z-average was taken into account; when PDI was higher than 0.5 , individual peaks were analyzed. Data were presented as mean $\pm \mathrm{SD}, n=3$ ( 8 measurements each).

\subsubsection{Transmission Electron Microscopy}

A complex of siRNA ( $3 \mu \mathrm{M}$ ) and 2Ag (in 12.5:1 dendron:siRNA molar ratio) was prepared in $10 \mathrm{mM}$ phosphate buffer, $\mathrm{pH} 7.4$, and $15 \mu \mathrm{L}$ of sample placed on 200 mesh copper grid with a carbon-coated surface for $10 \mathrm{~min}$. The sample was stained with $2 \%$ uranyl acetate for $20 \mathrm{~min}$, then washed with deionized water and dried at room temperature. Images were taken with a JEOL JEM-1010 transmission electron microscope (JEOL Ltd., Tokyo, Japan) at $80 \mathrm{kV}$.

\subsection{Cell Culture}

The HeLa (cervix adenocarcinoma) human cell line was purchased from ATCC (Manassas, VA, USA) and maintained under standard conditions in DMEM Medium (Thermo Fisher Scientific, Waltham, MA, USA) supplemented with $10 \%$ fetal bovine serum, penicillin $(100 \mathrm{U} / \mathrm{mL})$, and streptomycin $(100 \mu \mathrm{g} / \mathrm{mL})$ (Sigma-Aldrich, St. Louis, MO, USA) at $37^{\circ} \mathrm{C}$ in an atmosphere of $5 \% \mathrm{CO}_{2}$. Cells were sub-cultured 2-3 times per week.

Blood from healthy donors from the Central Blood Bank (Lodz, Poland) was anticoagulated with $3 \%$ sodium citrate. Erythrocytes were separated from blood plasma and leukocytes by centrifugation $\left(4000 \times g, 10 \mathrm{~min}, 4{ }^{\circ} \mathrm{C}\right)$, washed three times with PBS, and used immediately after isolation.

PBMCs (peripheral blood mononuclear cells) were isolated from blood samples using Histopaque 1077 (Sigma Aldrich, St. Louis, MO, USA) gradient $\left(1500 \times g, 15 \mathrm{~min}, 24^{\circ} \mathrm{C}\right)$ and cultured in RPMI-1640 Medium (Thermo Fisher Scientific, Waltham, MA, USA) supplemented with 10\% fetal bovine serum, 
penicillin $(100 \mathrm{U} / \mathrm{mL})$, and streptomycin $(100 \mu \mathrm{g} / \mathrm{mL})$ (Sigma-Aldrich, St. Louis, MO, USA) at $37^{\circ} \mathrm{C}$ in an atmosphere of $5 \% \mathrm{CO}_{2}$.

\subsection{Cellular Uptake Studies: Confocal Microscopy}

HeLa cells were seeded into 6-well plates at a density of $1 \times 10^{5}$ cells per well and treated with free siRNA-FITC (100 nM) and its complexes with $1 \mathrm{Ag}, 2 \mathrm{Ag}$, and 3Ag prepared in PBS in dendron:siRNA molar ratios of 55:1, 12.5:1, and 7.5:1, respectively, for $24 \mathrm{~h}$. The cells were subsequently washed with PBS, fixed with $4 \%$ formaldehyde for $30 \mathrm{~min}$, and stained with fluorescent dyes (DAPI (Sigma Aldrich, St. Louis, MO, USA) for 5 min for nuclei visualization and Texas Red ${ }^{\text {TM}}-X$ Phalloidin (Thermo Fisher Scientific, Waltham, MA, USA) for $20 \mathrm{~min}$ for actin visualization). Images were obtained with a Leica TCS SP8 microscope (Leica Microsystems GmbH, Wetzlar, Germany) at different excitation wavelengths (DAPI: $405 \mathrm{~nm}$, FITC: $495 \mathrm{~nm}$, Phalloidin: $565 \mathrm{~nm}$ ). Leica software was used to analyze the data.

\subsection{Hemotoxicity}

AgNPs in a dendron concentration range of $0.05-20 \mu \mathrm{M}$, and AgNP:siRNA complexes prepared in PBS in dendron:siRNA molar ratios of 55:1, 12.5:1, and 7.5:1 for 1Ag, 2Ag, and 3Ag, respectively, were added to the erythrocytes (at $2 \%$ hematocrit). The concentration of AgNPs in complexes was constant and equaled $20 \mu \mathrm{M}$. The samples were incubated at $37^{\circ} \mathrm{C}$ for 2 and $24 \mathrm{~h}$, centrifuged $(3000 \times g$, $10 \mathrm{~min}, 4^{\circ} \mathrm{C}$ ), and their absorbance was measured at $540 \mathrm{~nm}$ using a PowerWave HT Microplate Spectrophotometer (BioTek Instruments Inc., Winooski, VT, USA). The percentage of hemolysis was calculated using the following formula: $\mathrm{H}(\%)=($ A $540 \mathrm{~nm} /$ A water $540 \mathrm{~nm}) \times 100 \%$.

Data were presented as percentage of hemolysis, mean $\pm \mathrm{SD}, n=4$.

\subsection{Lymphocyte Proliferation}

PBMCs were seeded into 96-well black plates at a density of $1 \times 10^{5}$ cells per well. To induce the proliferation of lymphocytes, PBMC were stimulated with phytohemagglutinin (PHA, Sigma Aldrich, St. Louis, MO, USA, $10 \mu \mathrm{g} / \mathrm{mL}$ ).

The cells were treated with AgNPs in a dendron concentration range of $0.05-50 \mu \mathrm{M}$, and AgNP:siRNA complexes prepared in PBS in dendron:siRNA molar ratios of 55:1, 12.5:1, and 7.5:1 for $1 \mathrm{Ag}, 2 \mathrm{Ag}$, and $3 \mathrm{Ag}$, respectively, for $72 \mathrm{~h}$. The concentration of AgNPs in complexes was constant and equaled $20 \mu \mathrm{M}$. Following the incubation, resazurin was added to the culture medium to a final concentration of $10 \mu \mathrm{g} / \mathrm{mL}$ and the plates were incubated at $37^{\circ} \mathrm{C}$ in darkness to allow conversion of resazurin to resorufin. Fluorescence of metabolized resazurin was measured after 30 and $90 \mathrm{~min}$ at 530-nm excitation and 590-nm emission using a PowerWave HT Microplate Spectrophotometer (BioTek Instruments Inc., Winooski, VT, USA). Cell viability was calculated as the increase in resorufin fluorescence between 30 and $90 \mathrm{~min}$. Lymphocyte proliferation was presented as the percentage of viability of control (PHA-treated) cells, mean $\pm \mathrm{SD}, n=3$.

\subsection{Cytotoxicity Assay}

HeLa cells were seeded into 96-well transparent plates at a density of $1 \times 10^{4}$ cells per well. The cells were treated with AgNPs in a dendron concentration range of 5-100 $\mu \mathrm{M}$, and AgNP:siRNA complexes prepared in PBS in dendron:siRNA molar ratios of 55:1, 12.5:1, and 7.5:1 for 1Ag, $2 \mathrm{Ag}$, and $3 \mathrm{Ag}$, respectively, for 3 and $24 \mathrm{~h}$. The concentration of AgNPs in complexes was constant and equaled $100(1 \mathrm{Ag})$ or $50 \mu \mathrm{M}(2 \mathrm{Ag}$ and $3 \mathrm{Ag})$.

Following the incubation, the LDH assay was performed using a Pierce ${ }^{\mathrm{TM}} \mathrm{LDH}$ Cytotoxicity Assay Kit (Thermo Fisher Scientific, Waltham, MA, USA) according to the manufacturer's protocol. The absorbance at 490 and $680 \mathrm{~nm}$ was measured using a PowerWave HT Microplate Spectrophotometer (BioTek Instruments Inc., Winooski, VT, USA). To determine the LDH release, the 680-nm absorbance value was subtracted from the 490-nm absorbance value. The percentage of cytotoxicity was calculated 
using the following formula: cytotoxicity $(\%)=($ compound-treated LDH release- - spontaneous LDH release)/(maximum LDH release-spontaneous LDH release)

Data were presented as the percentage of viability of control (untreated) cells, mean $\pm \mathrm{SD}, n=3$.

\subsection{Statistics}

Statistical analysis was performed using Statistica (StatSoft Inc., Tulsa, OK, USA). The normality of distribution was assessed using the Shapiro-Wilk test and homogeneity of variance using the Brown-Forsythe test. Analysis of significance was performed using Kruskal-Wallis test with Dunn's post hoc test. In all tests, $p$ values $<0.05$ were considered statistically significant.

\section{Conclusions}

In this work, we proved that silver nanoparticles surface modified with carbosilane dendrons form stable complexes with siRNA, protecting it from enzymatic degradation and ensuring efficient cellular uptake. However, both the nanoparticles and complexes showed hemolytic and cytotoxic activity, which excludes their intravenous administration at the higher concentrations tested. The complexes did not show enhanced anticancer activity; therefore, further studies are needed involving different therapeutic siRNA or other cell lines showing varied expression of Bcl-2 family proteins. The use of other dendron:siRNA ratios could also be considered, giving complexes with a lower positive surface charge, thereby reducing the detrimental effects on cells.

Author Contributions: Conceptualization, E.P.-W.; synthesis of nanoparticles, C.E.P.-G., J.S.-N., R.G., F.J.d.1.M.; methodology, E.P.-W., V.A.; formal analysis, E.P.-W., M.G., K.H.; investigation, E.P.-W., K.H.; data curation, E.P.-W., M.G.; writing—original draft preparation, E.P.-W., M.G.; writing—review and editing, E.P.-W., M.G., B.K.-M., M.B.; supervision, E.P.-W., M.B.; project administration, E.P.-W., V.A.; funding acquisition, M.B. All authors have read and agreed to the published version of the manuscript.

Funding: This work was supported by the Polish National Agency for Academic Exchange, grant EUROPARTNER, No. PPI/APM/2018/1/00007/U/001; partially supported by the Belarusian Republican Foundation for Fundamental Research and State Committee of Science and Technology of Belarus, grants B19ARMG-002 and B20SLKG-002; based upon work from COST Action "Nano2Clinic. Cancer Nanomedicine - from the bench to the bedside" CA17140 supported by COST (European Cooperation in Science and Technology).

Acknowledgments: Confocal microscopy analysis was performed at the Laboratory of Microscopic Imaging and Specialized Biological Techniques, Faculty of Biology and Environmental Protection, University of Lodz.

Conflicts of Interest: The authors declare no conflict of interest.

\section{References}

1. Fuchs, U.; Damm-Welk, C.; Borkhardt, A. Silencing of disease-related genes by small interfering RNAs. Curr. Mol. Med. 2004, 4, 507-517. [CrossRef]

2. Mansoori, B.; Shotorbani, S.S.; Baradaran, B. RNA interference and its role in cancer therapy. Adv. Pharm. Bull. 2014, 4, 313-321. [PubMed]

3. Kaneda, Y. Gene therapy: A battle against biological barriers. Curr. Mol. Med. 2001, 1, 493-499. [CrossRef]

4. Chen, X.; Mangala, L.S.; Rodriguez-Aguayo, C.; Kong, X.; Lopez-Berestein, G.; Sood, A.K. RNA interference-based therapy and its delivery systems. Cancer Metastasis Rev. 2018, 37, 107-124. [CrossRef] [PubMed]

5. Rai, R.; Alwani, S.; Badea, I. Polymeric nanoparticles in gene therapy: New avenues of design and optimization for delivery applications. Polymers 2019, 11, 745. [CrossRef] [PubMed]

6. Hannon, G.J. RNA interference. Nature 2002, 418, 244-251. [CrossRef]

7. Hickerson, R.P.; Vlassov, A.V.; Wang, Q.; Leake, D.; Ilves, H.; Gonzalez-Gonzalez, E.; Contag, C.H.; Johnston, B.H.; Kaspar, R.L. Stability study of unmodified siRNA and relevance to clinical use. Oligonucleotides 2008, 18, 345-354. [CrossRef]

8. Whitehead, K.A.; Langer, R.; Anderson, D.G. Knocking down barriers: Advances in siRNA delivery. Nat. Rev. Drug Discov. 2009, 8, 129-138. [CrossRef] 
9. Thomas, C.E.; Ehrhardt, A.; Kay, M.A. Progress and problems with the use of viral vectors for gene therapy. Nat. Rev. Genet. 2003, 4, 346-358. [CrossRef]

10. Giacca, M.; Zacchigna, S. Virus-mediated gene delivery for human gene therapy. J. Control. Release 2012, 161, 377-388. [CrossRef]

11. Xin, Y.; Huang, M.; Guo, W.W.; Huang, Q.; Zhang, L.Z.; Jiang, G. Nano-based delivery of RNAi in cancer therapy. Mol. Cancer 2017, 16, 134. [CrossRef] [PubMed]

12. Hart, S.L. Synthetic vectors for gene therapy. Expert Opin. Ther. Pat. 2000, 10, 199-208. [CrossRef]

13. Kundu, P.P.; Sharma, V. Synthetic polymeric vectors in gene therapy. Curr. Opin. Solid State Mater. Sci. 2008, 12, 89-102. [CrossRef]

14. Kent, R.D.; Vikesland, P.J. Controlled evaluation of silver nanoparticle dissolution using atomic force microscopy. Environ. Sci. Technol. 2012, 46, 6977-6984. [CrossRef]

15. Austin, L.A.; Mackey, M.A.; Dreaden, E.C.; El-Sayed, M.A. The optical, photothermal, and facile surface chemical properties of gold and silver nanoparticles in biodiagnostics, therapy, and drug delivery. Arch. Toxicol. 2014, 88, 1391-1417. [CrossRef]

16. Sarkar, K.; Banerjee, S.L.; Kundu, P.P.; Madras, G.; Chatterjee, K. Biofunctionalized surface-modified silver nanoparticles for gene delivery. J. Mater. Chem. B 2015, 3, 5266-5276. [CrossRef]

17. Sztandera, K.; Gorzkiewicz, M.; Klajnert-Maculewicz, B. Gold nanoparticles in cancer treatment. Mol. Pharm. 2019, 16, 1-23. [CrossRef]

18. Ivanova, N.; Gugleva, V.; Dobreva, M.; Pehlivanov, I.; Stefanov, S.; Andonova, V. Silver nanoparticles as multi-functional drug delivery systems. In Nanomedicines; Farrukh, M.A., Ed.; IntechOpen: London, UK, 2018.

19. Desireddy, A.; Conn, B.E.; Guo, J.; Yoon, B.; Barnett, R.N.; Monahan, B.M.; Kirschbaum, K.; Griffith, W.P.; Whetten, R.L.; Landman, U.; et al. Ultrastable silver nanoparticles. Nature 2013, 501, 399-402. [CrossRef]

20. Nedelcu, I.A.; Ficai, A.; Sonmez, M.; Ficai, D.; Oprea, O.; Andronescu, E. Silver based materials for biomedical applications. Curr. Org. Chem. 2014, 18, 173-184. [CrossRef]

21. Wrobel, D.; Kolanowska, K.; Gajek, A.; Gomez-Ramirez, R.; de la Mata, J.; Pedziwiatr-Werbicka, E.; Klajnert, B.; Waczulikova, I.; Bryszewska, M. Interaction of cationic carbosilane dendrimers and their complexes with siRNA with erythrocytes and red blood cell ghosts. Biochim. Biophys. Acta (BBA)-Biomembr. 2014, 1838, 882-889. [CrossRef]

22. Ionov, M.; Lazniewska, J.; Dzmitruk, V.; Halets, I.; Loznikova, S.; Novopashina, D.; Apartsin, E.; Krasheninina, O.; Venyaminova, A.; Milowska, K.; et al. Anticancer siRNA cocktails as a novel tool to treat cancer cells. Part (A). Mechanisms of interaction. Int. J. Pharm. 2015, 485, 261-269. [CrossRef] [PubMed]

23. Dzmitruk, V.; Szulc, A.; Shcharbin, D.; Janaszewska, A.; Shcharbina, N.; Lazniewska, J.; Novopashina, D.; Buyanova, M.; Ionov, M.; Klajnert-Maculewicz, B.; et al. Anticancer siRNA cocktails as a novel tool to treat cancer cells. Part (B). Efficiency of pharmacological action. Int. J. Pharm. 2015, 485, 288-294. [CrossRef]

24. Peña-González, C.E.; Pedziwiatr-Werbicka, E.; Martín-Pérez, T.; Szewczyk, E.M.; Copa-Patiño, J.L.; Soliveri, J.; Pérez-Serrano, J.; Gómez, R.; Bryszewska, M.; Sánchez-Nieves, J.; et al. Antibacterial and antifungal properties of dendronized silver and gold nanoparticles with cationic carbosilane dendrons. Int. J. Pharm. 2017, 528, 55-61. [CrossRef] [PubMed]

25. Barrios-Gumiel, A.; Sanchez-Nieves, J.; Pérez-Serrano, J.; Gómez, R.; de la Mata, F.J. PEGylated AgNP covered with cationic carbosilane dendrons to enhance antibacterial and inhibition of biofilm properties. Int. J. Pharm. 2019, 569, 118591. [CrossRef]

26. Ciepluch, K.; Skrzyniarz, K.; Barrios-Gumiel, A.; Quintana, S.; Sánchez-Nieves, J.; de la Mata, F.J.; Maciejewska, B.; Drulis-Kawa, Z.; Arabski, M. Dendronized silver nanoparticles as bacterial membrane permeabilizers and their interactions with P. aeruginosa lipopolysaccharides, lysozymes, and phage-derived endolysins. Front. Microbiol. 2019, 10, 2771. [CrossRef]

27. Pedziwiatr-Werbicka, E.; Serchenya, T.; Shcharbin, D.; Terekhova, M.; Prokhira, E.; Dzmitruk, V.; Shyrochyna, I.; Sviridov, O.; Peña-González, C.E.; Gómez, R.; et al. Dendronization of gold nanoparticles decreases their effect on human alpha-1-microglobulin. Int. J. Biol. Macromol. 2018, 108, 936-941. [CrossRef] 
28. Shcharbin, D.; Pedziwiatr-Werbicka, E.; Serchenya, T.; Cyboran-Mikolajczyk, S.; Prakhira, L.; Abashkin, V.; Dzmitruk, V.; Ionov, M.; Loznikova, S.; Shyrochyna, I.; et al. Role of cationic carbosilane dendrons and metallic core of functionalized gold nanoparticles in their interaction with human serum albumin. Int. J. Biol. Macromol. 2018, 118, 1773-1780. [CrossRef] [PubMed]

29. Peña-González, C.E.; Pedziwiatr-Werbicka, E.; Shcharbin, D.; Guerrero-Beltrán, C.; Abashkin, V.; Loznikova, S.; Jiménez, J.L.; Muñoz-Fernández, M.Á.; Bryszewska, M.; Gómez, R.; et al. Gold nanoparticles stabilized by cationic carbosilane dendrons: Synthesis and biological properties. Dalton Trans. 2017, 46, 8736-8745. [CrossRef] [PubMed]

30. Trisciuoglio, D.; Tupone, M.G.; Desideri, M.; Di Martile, M.; Gabellini, C.; Buglioni, S.; Pallocca, M.; Alessandrini, G.; D'Aguanno, S.; Del Bufalo, D. BCL-XL overexpression promotes tumor progressionassociated properties. Cell Death Dis. 2017, 8, 3216. [CrossRef] [PubMed]

31. Kunze, D.; Kraemer, K.; Erdmann, K.; Froehner, M.; Wirth, M.P.; Fuessel, S. Simultaneous siRNA-mediated knockdown of antiapoptotic BCL2, Bcl-xL, XIAP and survivin in bladder cancer cells. Int. J. Oncol. 2012, 41, 1271-1277. [CrossRef] [PubMed]

32. de Mello, L.J., Jr.; Souza, G.R.R.; Winter, E.; Silva, A.H.; Pittella, F.; Creczynski-Pasa, T.B. Knockdown of antiapoptotic genes in breast cancer cells by siRNA loaded into hybrid nanoparticles. Nanotechnology 2017, 28, 175101. [CrossRef] [PubMed]

33. Shcharbin, D.; Pedziwiatr, E.; Bryszewska, M. How to study dendriplexes I: Characterization. J. Control. Release 2009, 135, 186-197. [CrossRef] [PubMed]

34. Guo, S.; Huang, Y.; Jiang, Q.; Sun, Y.; Deng, L.; Liang, Z.; Du, Q.; Xing, J.; Zhao, Y.; Wang, P.C.; et al. Enhanced gene delivery and siRNA silencing by gold nanoparticles coated with charge-reversal polyelectrolyte. ACS Nano 2010, 4, 5505-5511. [CrossRef] [PubMed]

35. Chen, G.; Wang, Y.; Xie, R.; Gong, S. Tumor-targeted pH/redox dual-sensitive unimolecular nanoparticles for efficient siRNA delivery. J. Control. Release 2017, 259, 105-114. [CrossRef] [PubMed]

36. Hom, C.; Lu, J.; Liong, M.; Luo, H.; Li, Z.; Zink, J.I.; Tamanoi, F. Mesoporous silica nanoparticles facilitate delivery of siRNA to shutdown signaling pathways in mammalian cells. Small 2010, 6, 1185-1190. [CrossRef] [PubMed]

37. Michlewska, S.; Ionov, M.; Maroto-Díaz, M.; Szwed, A.; Ihnatsyeu-Kachan, A.; Loznikova, S.; Shcharbin, D.; Maly, M.; Ramirez, R.G.; de la Mata, F.J.; et al. Ruthenium dendrimers as carriers for anticancer siRNA. J. Inorg. Biochem. 2018, 181, 18-27. [CrossRef]

38. Gorzkiewicz, M.; Buczkowski, A.; Appelhans, D.; Voit, B.; Pułaski, Ł.; Pałecz, B.; Klajnert-Maculewicz, B. Poly(propyleneimine) glycodendrimers non-covalently bind ATP in a pH-and salt-dependent manner-model studies for adenosine analogue drug delivery. Int. J. Pharm. 2018, 544, 83-90. [CrossRef]

39. Shcharbin, D.; Pedziwiatr, E.; Nowacka, O.; Kumar, M.; Zaborski, M.; Ortega, P.; de la Mata, F.J.; Gómez, R.; Muñoz-Fernandez, M.A.; Bryszewska, M. Carbosilane dendrimers NN8 and NN16 form a stable complex with siGAG1. Colloids Surf. B Biointerfaces 2011, 83, 388-391. [CrossRef]

40. Ionov, M.; Garaiova, Z.; Waczulikova, I.; Wróbel, D.; Pędziwiatr-Werbicka, E.; Gomez-Ramirez, R.; de la Mata, F.J.; Klajnert, B.; Hianik, T.; Bryszewska, M. siRNA carriers based on carbosilane dendrimers affect zeta potential and size of phospholipid vesicles. Biochim. Biophys. Acta (BBA)-Biomembr. 2012, 1818, 2209-2216. [CrossRef]

41. Ferenc, M.; Pedziwiatr-Werbicka, E.; Nowak, K.E.; Klajnert, B.; Majoral, J.P.; Bryszewska, M. Phosphorus dendrimers as carriers of siRNA—characterisation of dendriplexes. Molecules 2013, 18, 4451-4466. [CrossRef]

42. Krasheninina, O.A.; Apartsin, E.K.; Fuentes, E.; Szulc, A.; Ionov, M.; Venyaminova, A.G.; Shcharbin, D.; de la Mata, F.J.; Bryszewska, M.; Gómez, R. Complexes of pro-apoptotic siRNAs and carbosilane dendrimers: Formation and effect on cancer cells. Pharmaceutics 2019, 11, 25. [CrossRef] [PubMed]

43. Honary, S.; Zahir, F. Effect of zeta potential on the properties of nano-drug delivery systems-a review (Part 1 and 2). Trop. J. Pharm. Res. 2013, 12, 255-273.

44. Han, G.; Martin, C.T.; Rotello, V.M. Stability of gold nanoparticle-bound DNA toward biological, physical, and chemical agents. Chem. Biol. Drug Des. 2006, 67, 78-82. [CrossRef]

45. Jensen, L.B.; Pavan, G.M.; Kasimova, M.R.; Rutherford, S.; Danani, A.; Nielsen, H.M.; Foged, C. Elucidating the molecular mechanism of PAMAM-siRNA dendriplex self-assembly: Effect of dendrimer charge density. Int. J. Pharm. 2011, 416, 410-418. [CrossRef] [PubMed] 
46. Shakya, A.; Dougherty, C.A.; Xue, Y.; Al-Hashimi, H.M.; Banaszak Holl, M.M. Rapid exchange between free and bound states in RNA-dendrimer polyplexes: Implications on the mechanism of delivery and release. Biomacromolecules 2016, 17, 154-164. [CrossRef] [PubMed]

47. Pedziwiatr-Werbicka, E.; Shcharbin, D.; Maly, J.; Maly, M.; Zaborski, M.; Gabara, B.; Ortega, P.; de la Mata, F.J.; Gómez, R.; Muñoz-Fernandez, M.A.; et al. Carbosilane dendrimers are a non-viral delivery system for antisense oligonucleotides: Characterization of dendriplexes. J. Biomed. Nanotechnol. 2012, 8, 57-73. [CrossRef] [PubMed]

48. Zhang, X.F.; Liu, Z.G.; Shen, W.; Gurunathan, S. Silver nanoparticles: Synthesis, characterization, properties, applications, and therapeutic approaches. Int. J. Mol. Sci. 2016, 17, 1534. [CrossRef] [PubMed]

49. Fröhlich, E. The role of surface charge in cellular uptake and cytotoxicity of medical nanoparticles. Int. J. Nanomed. 2012, 7, 5577-5591. [CrossRef]

50. Liang, X.H.; Mungal, S.; Ayscue, A.; Meissner, J.D.; Wodnicki, P.; Hockenbery, D.; Lockett, S.; Herman, B. Bcl-2 protooncogene expression in cervical carcinoma cell lines containing inactive p53. J. Cell. Biochem. 1995, 57, 509-521. [CrossRef]

51. Lock, R.B.; Stribinskiene, L. Dual modes of death induced by etoposide in human epithelial tumor cells allow Bcl-2 to inhibit apoptosis without affecting clonogenic survival. Cancer Res. 1996, 56, 4006-4012. [PubMed]

(C) 2020 by the authors. Licensee MDPI, Basel, Switzerland. This article is an open access article distributed under the terms and conditions of the Creative Commons Attribution (CC BY) license (http://creativecommons.org/licenses/by/4.0/). 